\title{
ФОРМУВАННЯ КОМПОНЕНТІВ ПСИХОЛОГІЧНОЇ ГОТОВНОСТІ КАНДИДАТІВ ДО СЛУЖБИ В ЗБРОЙНИХ СИЛАХ УКРАЇНИ
}

\author{
Гаркуша I. В., Кайко В. I.
}

\section{ВСТУП}

Сучасна ситуація в Україні, спричинена збройним конфліктом на частині території Донецької й Луганської областей, зумовила підвищений інтерес до проблеми психологічної готовності до проходження військової служби як одного $з$ найважливіших факторів успішної військової діяльності. Військова служба, на відміну від інших видів соціальної діяльності, характеризується високою динамічністю: великими фізичними та психічними навантаженнями, швидкими переходами 3 одного виду діяльності на інший, а також чіткою організацією, суворою дисципліною. Професійна підготовка майбутніх військовослужбовців вимагає накопичення знань та уявлень про екстремальну ситуацію й особливості адаптації до неї, формування професійних якостей, релевантних вимогам професії, недостатній розвиток яких спричиняє ризик появи психосоматичних порушень, професійної деформації та вигорання, зниження ефективності виконання діяльності.

Проблематика висвітлена досить широким колом, важливими $\epsilon$ наукові праці щодо психологічної готовності людини до професійної діяльності, у яких відображені основні концепції вчених у рамках функціонального (Л. Балабанова, О. Іванова, М. Корольчук, В. Лебедєв, В. Молотай, Л. Нерсесян, М. Томчук ${ }^{1}$ ); особистісного (В. Барко, М. Дьяченко, В. Лефтеров та ін.) й особистісно-діяльнісного підходів (А. Деркач, Л. Кандибович, В. Корольчук, В. Пономаренко). Вивченням екстремальних ситуацій ы їх впливом на психіку людини, а також психологічних особливостей військової діяльності займалися I. Воробйова, Д. Грищенко, А. Желаго, О. Колесніченко, І І. Ліпатов, Я. Мацегора, В. Молотай, В. Пасічник, Н. Пенькова, I. Приходько, М. Товма, Н. Фетискин.

Натепер ресурси психологічної готовності недостатньо задіяні в професійній підготовці фахівців, хоча успішність професійної

\footnotetext{
${ }^{1}$ Томчук М.І. Психологія готовності учнів до служби у Збройних силах України. Вінниця : Нова Книга, 1993. 166 с.
} 
діяльності в особливих умовах багато в чому залежить від рівня психологічної готовності до неї. Отже, підвищення ефективності професійних компетенцій майбутніх військовослужбовців в умовах сучасної нестабільності, 3 одного боку, і нагальна необхідність удосконалення процесу адаптації кандидатів на військову службу в ході їх професійної підготовки в особливих умовах - 3 іншого, визначили головне протиріччя.

\section{1. Характеристика й компоненти психологічної готовності} кандидатів до військової служби у Збройних Силах України

Наявність усебічних сфер, щодо яких використовується поняття «психологічна готовність», свідчить про іiї складність, динамічність і багатогранність функціонування як психологічного феномена, що проявляється в найбільш важливі моменти життя особистості як психологічне утворення. У кожній професійній сфері «готовність» має конкретний специфічний прояв.

Вагомий внесок у вивченні готовності особистості до діяльності здійснили представники філософської науки. Їх точка зору полягає в тому, що готовність становить «утворення» певної взаємозалежної цілісності в структурі особистості, а саме його цілеспрямований соціальний розвиток і професійне самовдосконалення. Ця соціальна характеристика $\epsilon$ достовірним індикатором соціально-психологічних процесів, які виникають у життєдіяльності людини. У соціології й інших суспільних науках поняття «психологічна готовність» розглядається в контексті соціального переходу індивіда або групи людей з одного соціального стану в інший ${ }^{2}$.

В. Семиченко констатує, що для досягнення готовності до діяльності особистість проходить кілька етапів. Оскільки поставлене завдання, як правило, віддалене в часі, людина послідовно повинна виконати певну кількість завдань для досягнення мети ${ }^{3}$.

Н. Самоукіна зауважує, що на шляху готовності до діяльності на особистість діють дві групи факторів: об'єктивні (наявність професійних знань, умінь, навичок, якостей) і суб'єктивні (задатки і здібності, індивідуально-психологічні властивості й особливості, мотивація, рівень домагань) ${ }^{4}$.

${ }^{2}$ Евсюкова Н.И. Психолого-педагогические условия формирования готовности юношей допризывного возраста к службе в вооруженных силах: монография. Владимир : ВГГУ, 2009. 192 с.

Сиротин О.А. Психолого-педагогические основы индивидуализации спортивной подготовки дзюдоистов: монография. Челябинск, 1996. 315 с.

${ }^{4}$ Семиченко В.А. Психология деятельности. Киев : Издатель Эшке А.Н., 2002. $248 \mathrm{c}$. 
На думку М. Корольчука, готовність до професійної діяльності досягається вихованням в особистості високих моральних і психологічних якостей, дисциплінованості й ініціативи ${ }^{5}$, що включає:

- усебічний розвиток сукупності вольових якостей;

- формування особливих якостей психофізіологічної надійності;

- мобілізацію особистих можливостей і самоконтролю;

- розвиток стійкості до монотонії;

- подолання перешкод в екстремальних умовах;

- розвиток професійного мислення.

У психологічних словниках, які вийшли в 1983-2008 роках, відсутнє визначення поняття «психологічна готовність» як універсальної психологічної категорії. Поняття «психологічна готовність» до дії трактується як стан мобілізації всіх психофізіологічних систем людини, що забезпечують ефективне виконання визначених дій.

Конкретний стан готовності до дії визначається сумарністю факторів, що характеризують різні рівні, сторони готовності: фізичну підготовленість, необхідну нейродинамічну забезпеченість дій, психологічні умови готовності. Залежно від умов виконання дієвою може стати одна із цих сторін.

Традиційно психологічна готовність розглядається як психічний феномен, що зумовлює стійкість діяльності людини в полімотивованому просторі $^{6}$ (Л. Захарова, М. Котик, Б. Сосновський) ${ }^{7}$. Б. Братусь, В. Зінченко розглядають готовність у контексті знань, умінь, дій, реалізованих під час досягнення визначеної мети ${ }^{8}$.

Психологічна готовність значною мірою визначає вміння особистості прогнозувати, володіти мистецтвом антиципації, що дає змогу успішно справлятися 3 поставленими завданнями (Л. Регуш, М. Сторов $)^{9}$.

Існує багато термінів для позначення різних аспектів психологічної готовності, використання яких у різних авторів не збігається:

5 Дружинин В.Н. Психология общих способностей. Санкт-Петербург : Питер, 2002. $368 \mathrm{c}$.

6 Конопкин О.А. Психологические механизмы регуляции деятельности. Москва : Наука, 1980. 320 с.

7 Самоукина Н.В. Психология профессиональной деятельности : учебное пособие. Санкт-Петербург : Питер. 2003. 224 с.

8 Брушлинский А.В. Деятельность, действие и психическое как процесс. Вопросы психологии. 1984. № 5. С. 17-29.

${ }^{9}$ Евсюкова Н.И. Психолого-педагогические условия формирования готовности юношей допризывного возраста к службе в вооруженных силах : монография. Владимир : ВГГУ, 2009. 192 с. 
«емоціональна стійкість» ${ }^{10}$ (Е. Носенко ${ }^{11}$ В. Пономаренко ${ }^{12}$, О. Сиротін ${ }^{13}$ ), «толерантність до стресу» (Л. Собчик) $)^{14}$, «схильність до ризику», «готовність до ризику» (В. Бодров, С. Кір'янова), «психологічна готовність» (В. Авдєєв ${ }^{15}$, Т. Кабаченко ${ }^{16}$ ), «психічна готовність», «установка» (Д. Узнадзе $)^{17}$.

Психологічна готовність передбачає вміння приймати правильні рішення в складних умовах. На думку А. Пуні, вона характеризується стійкістю нервових процесів, упевненістю у своїх силах, прагненням досягнути поставленої мети, високою самооцінкою ${ }^{18}$.

М. Левітов уважає, що психічні стани людини впливають на рівень готовності особистості до виконання певної дій. Він виділяє тривалу й тимчасову (передстартову) готовності. У свою чергу, передстартовий стан має три види: звичайний, підвищений, знижений. Звичайна готовність у людини виникає перед повсякденною роботою, до якої вона звикла. Творчий характер роботи, новизна викликають стан підвищеної готовності. Знижена готовність проявляється в помилкових діях, відволіканні уваги, незібраності ${ }^{19}$.

Л. Кондрашова до поняття психологічної готовності включає професійні знання й навички, а також риси особистості, які забезпечують успішне виконання професійних завдань. Психічні процеси та властивості особистості завжди відповідають конкретним умовам і завданням життя ${ }^{20}$.

${ }^{10}$ Моргун В.Ф. Емоційний інтелект у багатовимірній структурі особистості. Постметодика. Полтава, 2010. № 6. С. 2-14.

${ }^{11}$ Максименко С.Д. Експериментальна психологія : підручник. Київ : Центр учбової літератури, 2008. 360 с.

12 Пономаренко В.А. Социально-психологическое содержание боевого стресса. Психологический журнал. 2004. Т. 25. № 3. С. 98-102.

13 Сиротин О.А. Психолого-педагогические основы индивидуализации спортивной подготовки дзюдоистов : монография. Челябинск, 1996. 315 с.

14 Собчик Л.Н. Стандартизированный многофакторный метод исследования личности СМИЛ (ММРI). Санкт-Петербург : Речь, 2000. 219 с.

15 Авдеев В.В. Психотехнология решения проблемных ситуаций. Москва : Феникс, 1992. 128 с.

16 Кабаченко Т.С. Методы психологического воздействия : учебное пособие. Москва : Пед. о-во России, 2000. 530 с.

${ }_{17}$ Узнадзе Д.Н. Психологические исследования. Москва : Наука, 1966. 233 с

${ }^{18}$ Пуни А.Ц. Некоторые психологические вопросы готовности к соревнованиям в спорте. Москва : Физкультура и спорт, 1973. С. 5.

19 Левитов Н.Д. О психических состояниях человека. Москва : Просвещение, 1964. $344 \mathrm{c}$.

${ }^{20}$ Кондрашова Л.В. Моральна психологічна готовність студента до вчительської діяльності. Київ : Вища школа, 1987. С. 40. 
Формування готовності як результат психолого-педагогічного впливу вивчала М. Солодкова, розуміючи психологічну готовність як передбачення майбутньої дії з метою досягнення будь-яких результатів i необхідності мобілізації психіки на подолання перешкод, що виникають.

В. Дружинін уважає, що мобілізація всіх ресурсів людини на виконання конкретного завдання - психічний стан, який дає змогу успішно виконувати свої обов'язки, використовувати знання, особистісні якості, досвід, за необхідності перебудовувати діяльність ${ }^{21}$.

Г. Дунін наголосив, що після усвідомлення поставленим перед людиною завдання виникає стан готовності до діяльності. Він характеризується цілеспрямованим спрямуванням психічних процесів на подолання труднощів i досягнення потрібного результату. Мобілізація всіх сил дає змогу виявити правильне співвідношення наявних i потенційних можливостей для прийняття необхідних правильних рішень ${ }^{22}$.

Складниками готовності до діяльності є реалізація людиною двох груп своїх можливостей - неспецифічних і специфічних. Неспецифічні можливості дають змогу мобілізувати свій досвід, почуття, волю для вирішення поставлених завдань, підтримати внутрішню рівновагу; специфічні можливості розвивають професійно важливі якості особистості: професійну мотивацію, рівень домагань, здібності.

Психологічна готовність $є$ обов'язковою передумовою майбутньої діяльності. Готовність до дії - це мобілізація всіх психофізіологічних систем організму, яка забезпечує успішне виконання необхідних дій ${ }^{23}$.

У науково-дослідницькому аспекті вивчення проблеми готовності призовників до військової строкової служби розглядається у військовій та екстремальній психології ${ }^{24}$ i урахуванням найбільш актуальних мотивів діяльності для юнацького віку: самоствердження, саморозвитку, досягнення.

Готовність молоді до військової строкової служби досліджена в рамках соціологічних теорій. За останні п'ятнадцять років готовність

${ }^{21}$ Дружинин В.Н. Психология общих способностей. Санкт-Петербург : Питер, 2002. 368 c.

22 Дунин Г.С. Психологическая готовность сотрудников МВД России к деятельности в чрезвычайных ситуациях. Вестник Московского университета МВД России. Москва, 2006. № 1. С. 133-136.

${ }^{23}$ Равикович С.И. Развитие психологической готовности старших подростков к производительному труду : автореф. дисс. ... канд. психол. наук : 19.00.07 «Педагогическая психология». Москва, 1986. 14 с.

24 Дубовицкая Т.Д. К проблеме диагностики учебной мотивации. Bonpocbl психологи. 2006. № 1. С. 73-78. 
молоді до військової строкової служби розглядається значною мірою як готовність до професійної діяльності за контрактом (інтерес до військової служби зумовлено матеріальною винагородою та певними соціальними пільгами) $)^{25}$.

В Україні військові психологи розуміють психологічну готовність призовників до служби в умовах ризику як бажання випробувати свої можливості та здобуті до моменту призову знанняя ${ }^{26}$.

Військова діяльність - це колективна форма людської праці, де вище цінуються не індивідуальна військова майстерність, а колективна. Цього вимагає характер сучасної війни й використаної на ній бойової техніки та зброї. Тому потрібно водночас формувати як індивідуальну, так і колективну майстерність підлеглих.

Військова діяльність як складник військової служби спрямована в мирні часи на підтримання бойової готовності збройних сил для забезпечення життєво важливих інтересів країн, під час війни - на знищення ворога. Навчально-бойова діяльність готує військовослужбовців до можливих бойових дій, відбуваючись безпосередньо у військових частинах, навчальних військових підрозділах Збройних Сил України; бойова - проходить в умовах військової сутички ${ }^{27}$. У реальних бойових умовах військові ризикують життям, бойові дії потребують високого напруження всіх фізичних і духовних сил. Нова зброя й техніка, сучасні методи ведення бою різко збільшили психологічні труднощі, з якими стикаються військовослужбовці. Критичні ситуації та різного роду труднощі потребують від них знань, мужності, вправності, спритності, кмітливості, витривалості, володіння собою ${ }^{28}$.

Натепер у світі існує декілька способів комплектування армії: за призовом, за контрактом (добровільний) і за змішаним принципом. Стосовно принципу прийняття на службу за контрактом у юнаків може виникати значно вищий рівень соціально-психологічної готовності, ніж у призовників, які приймаються на строкову військову службу. Згідно 3 Концепцією оборони та будівництва Збройних сил України, перспектива

${ }^{25}$ Матохнюк Л.О. Формування психологічної готовності майбутніх інженерівприкордонників до професійної діяльності : дис. ... канд. псих. наук : 19.00.07. Хмельницький, 2006. 219 с.

${ }^{26}$ Шандрук С.К. Специфіка підготовки практичних психологів до професійної діяльності: проблеми підготовки і підвищення кваліфікації практичних психологів у вищих навчальних закладах. Київ : Ніка-Центр, 2002. С. 32-34.

27 Maddi S.R. The personality construct of hardiness, III: Relationships with repression, innovativeness, authoritarianism, and performance. Journal of Personality. 2006. Vol. 74. P. 575-598. DOI: 10.1111/j.1467-6494.2006.00385.x.

${ }^{28}$ Orr S.P., Pitman R.K., Lasko N.B., Herz L.R. Psychophysiologic assessmen of post-traumatic stress disorder imagery in World War II and Korean combat veterans. 1993. V. 102. P. 152. DOI: 10.1037/0021-843X. 102. 1. 152. 
переходу до виключно добровільного способу комплектування військових формувань передбачається й в Україні. Професійність як один із принципів підбору кадрів i комплектування державних структур проголошується останнім часом не тільки у військовій галузі, а й у будьякій іншій сфері суспільної діяльності. Під професіоналізмом розуміються глибокі та всебічні знання й володіння практичними навиками в будь-якій галузі суспільно корисної діяльності ${ }^{29}$.

Головним аргументом прихильників професійної армії в усьому світі $\epsilon$ те, що мотивація до військової служби у військовослужбовців за контрактом значно вища, порівняно 3 призовниками. Також в умовах швидкого розвитку військової техніки для оволодіння нею треба навчатися довгі роки, тому молодий ненавчений призовник не може виконувати обов'язки військової служби належним чином. Психологічна мотивація військовослужбовця, який добровільно вступив на військову службу, принципово відрізняється від мотивації призовника, який ставиться до військової служби як до нудного, тимчасового обов'язку. Безперечно, він абсолютно не зацікавлений у якості виконання своїх обов'язків, у бережливому ставленні до техніки. Отже, на військовослужбовців необхідно поширити універсальний принцип стимулювання будь-якої суспільно корисної діяльності. Саме військова служба за контрактом дає змогу зробити 3 військовослужбовців справжніх професіоналів своєї справи, що $є$ не тільки важливим для збройних сил і доцільним для техніки, а й необхідним для безпеки населення держави та людства загалом ${ }^{30}$.

Науковці (О. Кокун ${ }^{31}$, I. Окуленко ${ }^{32}$ ) по-різному визначають компоненти психологічної готовності до військової діяльності, застосовуючи різні підходи до розуміння психіки, сутності готовності. Так, у дослідженнях психологічної, фізичної та функціональної підготовленості сучасної молоді допризовного і призовного віку до служби в Збройних силах Ю. Сисоєв виділив складові компоненти готовності до служби, а саме: особистісний, мотиваційний та

29 Дьяченко М.И. Психологические проблемы готовности к деятельности. Минск : БГУ, 1976. 176 с.

30 Ягупов В.В. Військова психологія : підручник для студентів ВНЗ. Київ : Тандем, 2004. 376 с.

31 Кокун О.М. Діагностування психологічної готовності військовослужбовців військової служби за контрактом до діяльності у складі миротворчих підрозділів : методичний посібник. Київ : НДЦ ГП ЗСУ, 2011. 153 с.

32 Окуленко I.М. Психологічна готовність льотного складу до діяльності в умовах тривалих перерв між польотами : дис. ... канд. психол. наук : 19.00.09. Хмельницький, 2007. 304 с. 
операційний; сформував вимоги, необхідні для підготовки молоді 3 урахуванням специфіки військової служби.

Ю. Голованов уважає психологічну готовність до військової діяльності станом психіки особистості, який включає індивідуальні, емоційно-вольові, когнітивні, типологічні особливості людини. Він експериментальним шляхом довів, що успішна військова діяльність залежить від рівня сформованості у військовослужбовців основних компонентів психологічної готовності: мотиваційного, вольового, когнітивного, регуляторного й типологічного ${ }^{33}$.

Л. Матохнюк у психологічній готовності майбутніх офіцерів до успішного виконання професійної діяльності визначила три компоненти: мотиваційно-ціннісний (визначає спрямованість на професійну діяльність), когнітивний (охоплює систему знань, необхідних для успішної діяльності), операційно-діяльнісний (характеризує низку здібностей особистості щодо ефективного виконання службових функцій) ${ }^{34}$.

О. Колесніченко виділив п'ять основних компонентів: когнітивний, мотиваційний, вольовий, типологічний і регуляторний ${ }^{35}$. В. Ягупов головними структурними елементами психологічної готовності військовослужбовців уважає мотиваційний, пізнавальний, емоційний i вольовий ${ }^{36}$.

На думку I. Окуленко, психологічна готовність до складних екстремальних видів діяльності включає низку компонентів, основними з яких є мотиваційні, пізнавальні, емоційні, вольові ${ }^{37}$.

У час соціальних трансформацій, що зумовлюють нові соціальноекономічні умови професійної діяльності, особливої ваги набувають внутрішні, психологічні ресурси особистості.

Отже, готовність є базовою умовою успішного виконання будь-якої діяльності, передбачаючи усвідомлення особистістю поставленого перед нею завдання з наступним моделюванням схем безпосередніх

33 Голованов Ю.Н. Оценка и формирование психологической готовности сотрудников специальных подразделений МВД России к деятельности в экстремальных ситуациях : дис. ... канд. психол. наук : 19.00.06. Санкт-Петербург, 2001. 167 с.

34 Матохнюк Л.О. Формування психологічної готовності майбутніх інженерівприкордонників до професійної діяльності : дис. ... канд. психол. наук : 19.00.07. Хмельницький, 2006. 219 с.

35 Колесніченко О.С. Психологічна готовність працівників МНС України до професійної діяльності в екстремальних умовах : автореф. дис. ... канд. психол. наук : 19.00.09. Харьків, 2011. 23 с.

36 Ягупов В.В. Військова психологія : підручник для студентів ВНЗ. Київ : Тандем, 2004. $376 \mathrm{c}$.

37 Окуленко I.M. Психологічна готовність льотного складу до діяльності в умовах тривалих перерв між польотами : дис. ... канд. психол. наук : спец. 19.00.09. Хмельницький, 2007. 304 с. 
дій, що виявляється згодом у предметних діях. Готовність до служби в армії полягає в здатності успішного виконання вимог військової діяльності на початковому етапі, адже високий рівень готовності скорочує адаптаційний період, даючи змогу зменшити зусилля для зосередження їх на вдосконаленні необхідних для служби навичок і вмінь; узагальнення результатів теоретичного аналізу уможливило виділення трьох основних компонентів психологічної готовності призовників до військової служби: особистісного (бажання служити в армії, інтересу до військової діяльності, почуття обов'язку, патріотизму, розуміння соціальної значущості військової служби); емоційно-вольового (здатності особистості регулювати свої емоційні стани, витримувати складні умови, обмеження, труднощі армійського життя); інтелектуального (рівень розвитку знань, навичок і вмінь, необхідних молодому воїнові).

Стійкість, стабільність і якість професійної діяльності зумовлюється особливостями психологічної готовності фахівця, формування якої $\epsilon$ результатом психолого-педагогічного впливу щодо системи якостей особистості: відповідальності, громадської активності, упевненості, витримки, наполегливості, почуття обов'язку, волі, готовності до захисту Вітчизни ${ }^{38}$.

\section{2. Динаміка інтелектуального, емоційно-вольового й особистісного компонентів готовності кандидатів до служби в Збройних силах України в умовах формувального експерименту}

В екстремальних ситуаціях відбувається перебудова регуляторних функцій психіки, здійснюється іiї перехід на новий рівень активності, що залежить від готовності військовослужбовця до діяльності в таких ситуаціях. Зміст і структура психологічної готовності до служби в Збройних силах України визначаються вимогами діяльності до психічних процесів, станів, досвіду, знань, навичок і вмінь майбутніх військових. Установлення психологічних компонентів готовності до складних видів діяльності уможливили вирішення питання ефективності процесу формування психологічної готовності в кандидатів на військову службу. Засоби та прийоми формування психологічної готовності повинні застосовуватися 3 урахуванням характеру службово-бойової діяльності й змісту виконуваних завдань. Один із засобів підтримки готовності полягає у створенні зовнішніх умов щодо забезпечення діяльності майбутніх військовослужбовців.

${ }^{38}$ Пономаренко В.А. Социально-психологическое содержание боевого стресса. Психологический журнал. 2004. Т. 25. № 3. С. 98-102. 
Дослідження особливостей психологічної готовності до військової служби в Збройних силах України проведено за допомогою методик, які спрямовані на виявлення рівнів розвитку компонентів психологічної готовності кандидатів на військову службу в Збройних силах України. Цей комплекс складається 3 методики оцінювання адаптаційних здібностей особистості (багаторівневий особистісний опитувальник «Адаптивність200»), методики визначення рівня нервово-психічної стійкості (анкета «Прогноз») за В. Бодровим, багатофакторного особистісного опитувальника Р. Кеттелла (16 PF-105-C). Кожна методика визначає кількісні та якісні результати, що сприяє різнобічному аналізу особливостей психологічної готовності респондентів.

Для проведення констатувального експерименту сформовано вибірку в кількості 48 кандидатів на військову службу в Збройних силах України. В експериментальній частині роботи вирішено з'ясувати рівень психологічної готовності до військової служби та проаналізувати отримані дані. По всіх вибраних методиках вирахувано загальний результат кількісних показників із наступним вираженням його у відсотках.

Загалом по вибірці констатуємо, що 88\% досліджуваних мають рівень нервово-психічної стійкості й поведінкової регуляції достатній для служби в армії. Отже, більшість кандидатів на військову службу мають стійкий рівень працездатності у звичних умовах життєдіяльності. Проте у $12 \%$ юнаків пониженого, недостатнього й украй низького рівнів нервово-психічної стійкості нестабільний рівень працездатності в екстремальних умовах діяльності, ускладнена адаптація до нових умов життєдіяльності.

У $84 \%$ кандидатів на військову службу рівень комунікативного потенціалу коливається від середнього до дуже високого. Вони без особливих ускладнень адаптуються до нового колективу, до критичних зауважень ставляться адекватно, здатні коригувати свою поведінку; у спілкуванні не конфліктні; досить адекватно оцінюють свою роль у колективі. Проте стурбованість викликає наявність задовільного, пониженого й украй низького рівнів комунікативного потенціалу (по 4\%).

Рівень морально-етичної нормативності 92\% призовників достатній. Вони загалом зорієнтовані на дотримання загальноприйнятих і соціально схвалених норм поведінки, корпоративних вимог; у повсякденній життєдіяльності групові інтереси, як правило, переважають над особистісними. Проте наявні $8 \%$ низького рівня, що зумовлено низьким рівнем соціалізації, недотриманням загальноприйнятих норм поведінки.

Вагомою характеристикою кандидатів на військову службу є рівень стійкості до бойового стресу. 79\% юнаків мають достатній і високий 
рівні стійкості, що відповідає вимогам до військовослужбовців в умовах бойової діяльності. 17\% призовників із задовільним рівнем стійкості показують мінімальну відповідність указаним вище вимогам; 4\% досліджуваних мають недостатній рівень розвитку адаптаційних можливостей особистості.

Дослідження засвідчує, що $84 \%$ призовників мають достатньо високий рівень військово-професійної спрямованості за відсутніх ознак девіантних форм поведінки. 4\% кандидати мають виражені ознаки девіантної поведінки, що потребує подальшого вивчення.

Отже, рівень сформованості психологічної готовності кандидатів $є$ недостатнім, що зумовлює необхідність упровадження соціальнопсихологічного тренінгу, який би сприяв підвищенню їхнього рівня 3 метою створення зони найближчого професійного розвитку. Результати констатувального дослідження загалом дають підставу для конкретної роботи щодо подальшого розвитку психологічної готовності до служби в Збройних силах України.

Найбільш ефективною допомогою вважаємо групову форму роботи, a саме метод соціально-психологічного тренінгу (СПТ), який застосовують у системі підготовки спеціалістів різного профілю.

Соціально-психологічний тренінг проводиться за визначеним тренером-психологом сценарієм. Зважаючи на деяку спонтанність тренінгових процесів, будь-яка програма $\epsilon$ загальною схемою, стратегічним планом дій і не передбачає механічного повторення. Тренер детально продумує плани занять, корегуючи їх під реально існуючу групу, реагуючи на зміни психологічного стану учасників під час виконання поставлених завдань програми. Для досягнення мети тренінгу тренеру потрібно створити умови для формування групи високого рівня розвитку, що забезпечується принципами організації тренінгових занять, зорієнтованих на формування психологічної готовності до військової служби (таблиця 1). 
Таблиця 1

Принципи організації військовооріснтаційних тренінгових занять

\begin{tabular}{|c|c|c|}
\hline $\begin{array}{c}\text { № } \\
\text { 3/II }\end{array}$ & Найменування & Зміст організаційного принципу \\
\hline 1 & Активність кандидатів & $\begin{array}{l}\text { Ініціативність, зацікавленість, } \\
\text { висловлювання власної думки, свого } \\
\text { ставлення до проблеми, залучення до } \\
\text { обговорення та програвання } \\
\text { екстремальних військових ситуацій, } \\
\text { запропонованих самими учасниками. }\end{array}$ \\
\hline 2 & Дослідницька позиція & $\begin{array}{l}\text { Створення в процесі тренінгової роботи } \\
\text { ситуацій самостійного розв'язання } \\
\text { проблем, прийняття рішень тощо. }\end{array}$ \\
\hline 3 & $\begin{array}{l}\text { Об'єктивація } \\
\text { поведінки }\end{array}$ & $\begin{array}{l}\text { Переведення на початку занять } \\
\text { поведінки кандидатів на військову } \\
\text { службу із імпульсивного на } \\
\text { об'єктивований рівень, підтримка на } \\
\text { ньому; при цьому важливим } є \\
\text { особливим чином організований } \\
\text { зворотний зв'язок. }\end{array}$ \\
\hline 4 & $\begin{array}{l}\text { Партнерське } \\
\text { спілкування }\end{array}$ & $\begin{array}{l}\text { Визнання цінності іншої особистості, її } \\
\text { думок, інтересів, максимально можливе } \\
\text { врахування інтересів усіх учасників, } \\
\text { довіра, толерантність і рівноправність у } \\
\text { міжособистісній взаємодії учасників. }\end{array}$ \\
\hline
\end{tabular}

Крім зазначених принципів роботи тренінгових груп, можна говорити й про специфічний принцип роботи тренера, який полягає в постійній рефлексії групових процесів. Ця рефлексія здійснюється за рахунок того, що тренер, приступаючи до проведення тренінгу, плануючи роботу на день або безпосередньо в процесі роботи, ставить собі три запитання: «Якої мети хочу досягти?», «Чому хочу досягти цієї мети?», «Якими засобами збираюсь їі досягти?»

Ігрові методи застосовуються для структурування активності кандидатів на військову службу, подолання напруження учасників, вияву особистісних проблем, інтенсифікації процесу навчання тощо.

Завдяки методам розвитку професійної військової перцепції учасники групи набувають уміння розуміти й оцінювати як власні життєві наміри, так і наміри інших членів групи, змістової та оцінної інтерпретації об'єкта сприйняття.

У результаті психогімнастичних вправ можуть відбуватися зміни в стані групи загалом та окремих іiі учасників. Вправи можуть бути спеціалізовано військовими, а можуть мати більш універсальний характер. Наприклад, можна запропонувати учасникам описати 
представника конкретного роду військ вербально, потім намалювати його, виразити рухами. У результаті збільшуються можливості усвідомлення, 3'являються нові грані сприйняття однієї й тієї самої спеціалізації. Варто зазначити, що вдале поєднання методів і прийомів групової роботи сприяє результативності роботи як групи загалом, так i кожної особистості.

Для виділення із 48 обстежених призовників учасників експериментальної групи проводимо кластерний аналіз. Первинні дані за трьома методиками беремо в стенах. Як критерії з кожної методики приймаємо по одному показнику. 3 першої - особистісний потенціал соціально-психологічної адаптації, з другої - нервово-психічну стійкість, із третьої - емоційну стійкість. У результаті аналізу одержуємо три кластери: перший - призовники, що мають по всіх показниках низькі рівні; другий призовники, що мають по всіх трьох показниках високі рівні; третій призовники, що мають по одних показниках - високі, по інших - низькі рівні. Юнаки першого кластеру становлять експериментальну групу. Призовники другого і третього кластерів у сумі становлять контрольну групу. У результаті розподілу одержуємо контрольну групу з 37 й експериментальну групу з 11 чоловік.

Далі 3'ясуємо, чи є між контрольною та експериментальною групами розбіжності по всіх трьох методиках до тренінгу. Відповідь на запитання дає критерій Манна-Уітні. Критерій дає можливість оцінити розбіжності між двома вибірками за рівнем якого-небудь показника, який вимірюється кількісно.

Таблиця 2

\section{Показники контрольної та експериментальної груп} за критерісм Манна-Уітні

\begin{tabular}{|c|c|c|}
\hline $\begin{array}{c}\text { № } \\
\text { 3/п }\end{array}$ & Показники & Рівень значущості \\
\hline 1 & Особистісний потенціал соціально- & 0,000 при $\mathrm{p} \leq 0,01$ \\
\hline 2 & психологічної адаптації & 0,049 при $\mathrm{p} \leq 0,05$ \\
\hline 3 & Військово-професійна спрямованість & 0,001 при $\mathrm{p} \leq 0,01$ \\
\hline 4 & Схильність до суїцидального ризику & 0,042 при $\mathrm{p} \leq 0,05$ \\
\hline 5 & Нервово-психологічна стійкість & 0,014 при $\mathrm{p} \leq 0,05$ \\
\hline 6 & Фактор С - емоційна стійкість & 0,000 при $\mathrm{p} \leq 0,01$ \\
\hline
\end{tabular}

Як видно 3 таблиці 2, між контрольною й експериментальною групами $\epsilon$ статистично значущі розбіжності (за особистісним потенціалом соціально-психологічної адаптації, схильністю до девіантних форм поведінки й фактором $\mathrm{C}$ - на рівні значущості менше 
ніж $0,1 \%$, за військово-професійною спрямованістю, схильністю до суїцидального ризику й нервово-психологічною стійкістю - на рівні значущості менше ніж 5\%). Отже, кандидати на військову службу експериментальної групи мають низьку психологічну готовність.

Перевіримо результативність проведеного тренінгу, для чого порівняємо результати опитування експериментальної групи до й після тренінгу (таблиця 3).

Таблиця 3

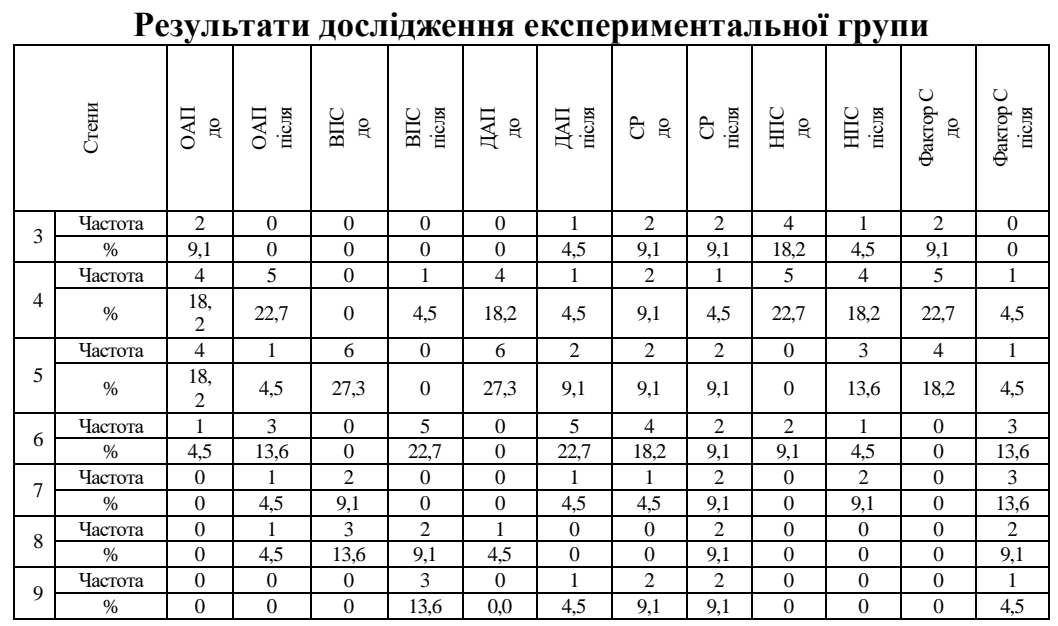

За даними таблиці 3 побудуємо гістограму розподілу рівнів стійкості призовників до бойового стресу (рис. 1). По горизонталі рівні стійкості до бойового стресу, по вертикалі - кількість досліджуваних у відсотках. 


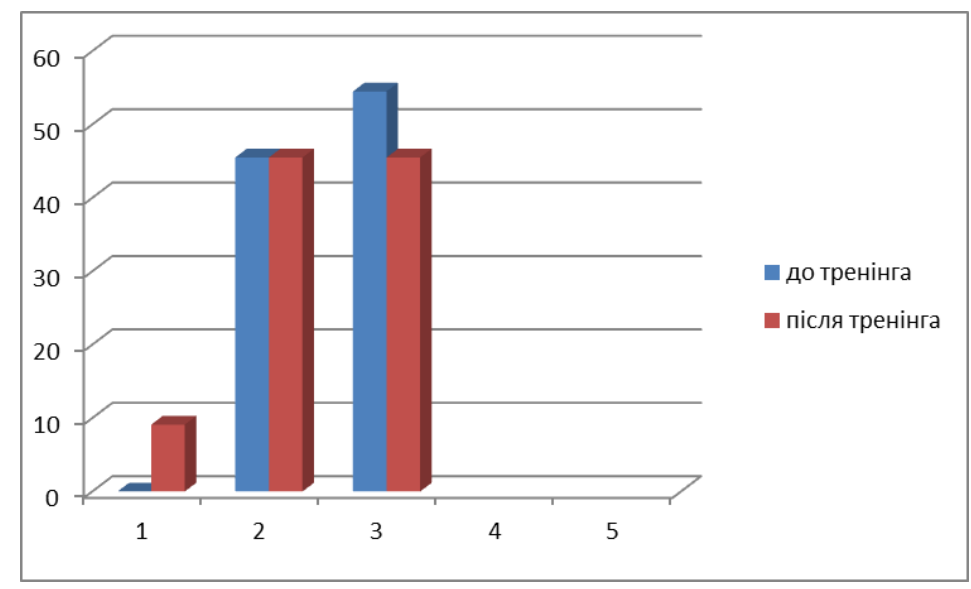

Рис. 1. Гістограма розподілу рівнів стійкості до бойового стресу призовників експериментальної групи до та після тренінгу: 1 - високий рівень, 2 - достатній рівень, 3 -задовільний рівень

Як бачимо з рис. 1, 45,5\% досліджуваних мають достатній рівень стійкості, розвитку адаптаційних можливостей, що в основному відповідає вимогам до військовослужбовців в умовах бойової діяльності. Після проведення тренінгу в 9,1\% призовників рівень стійкості підвищується до високого; 3 54,5\% до 45,5\% зменшується задовільний рівень стійкості.

За допомогою методів математичної статистики підрахуємо, чи покращив тренінг результати готовності призовників експериментальної групи до військової служби. Відповідь на запитання дає критерій W-Уілкоксона.

Таблиця 4

Показники експериментальної групи до й після тренінгу за критерієм W-Уілкоксона

\begin{tabular}{|c|c|c|}
\hline $\begin{array}{c}\text { № } \\
\text { 3/п }\end{array}$ & Показники & Рівень значущості \\
\hline 1 & Особистісний потенціал соціально & 0,011 при $\mathrm{p} \leq 0,05$ \\
\hline 2 & психологічної адаптації & 0,013 при $\mathrm{p} \leq 0,05$ \\
\hline 3 & Схильність до дефесіантних форм поведінки & 0,033 при $\mathrm{p} \leq 0,05$ \\
\hline 4 & Схильність до суїцидального ризику & 0,035 при $\mathrm{p} \leq 0,05$ \\
\hline 5 & Нервово-психологічна стійкість & 0,008 при $\mathrm{p} \leq 0,01$ \\
\hline 6 & Фактор С - емоційна стійкість & 0,021 при $\mathrm{p} \leq 0,05$ \\
\hline
\end{tabular}


Аналіз даних таблиці 4 дав змогу встановити за всіма показниками статистично значущі відмінності (за особистісним потенціалом соціально психологічної адаптації, військово-професійній спрямованості, схильністю до девіантних форм поведінки, схильністю до суїцидального ризику й фактором $\mathrm{C}$ - на рівні значущості менше ніж $5 \%$; за нервово-психологічною стійкістю - на рівні значушості менше $1 \%$ ), що засвідчує підвищення рівня готовності до служби в Збройних силах України у призовників експериментальної групи.

Для підтвердження результатів тренінгу проведемо ще одну перевірку - порівняємо контрольну групу з експериментальною після тренінгу. За даними таблиці 4 побудуємо гістограму розподілу рівнів стійкості призовників до бойового стресу (рис. 2). По горизонталі рівні стійкості до бойового стресу, по вертикалі - кількість досліджуваних у відсотках.

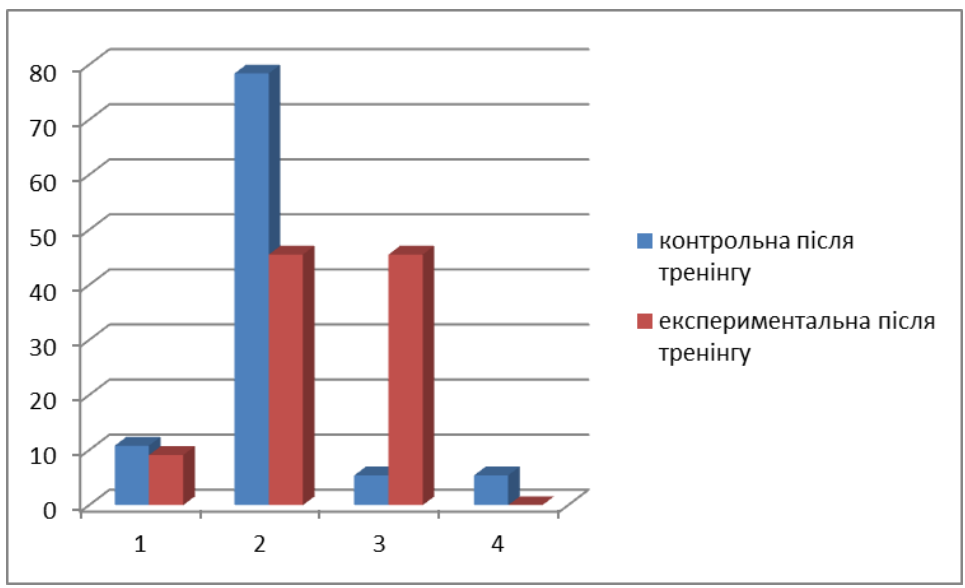

Рис. 2. Гістограма розподілу рівнів стійкості до бойового стресу призовників контрольної та експериментальної груп після тренінгу:

1 - високий рівень, 2 - достатній, 3 - задовільний, 4-низький

Як бачимо 3 рис. 2, досліджувані експериментальної групи після тренінгу та контрольної мають майже одинакові високі рівні стійкості до бойового стресу $(9,1 \%$ i $10,8 \%$ відповідно), що в основному відповідає вимогам до військовослужбовців в умовах бойової діяльності. Після проведення тренінгу в 78\% призовників рівень стійкості відповідає достатньому (проти 45,5\% у контрольній групі), у $5,4 \%$ - задовільному (проти $45,5 \%$ у контрольній групі). 


\section{ВИСНОВКИ}

Ураховуючи викладене, можна зробити висновок, що становлення психологічних особливостей готовності до складних видів діяльності уможливило вирішення питання ефективності процесу формування психологічної готовності кандидатів на військову службу. Найбільш ефективною допомогою $є$ групова форма роботи, а саме метод соціально-психологічного тренінгу (СПТ), який застосовують у системі підготовки спеціалістів різного профілю. Принцип діяльнісного опосередкування в організації процесів підготовки до військової служби дає змогу успішно вирішувати завдання 3 формування психологічної готовності майбутніх військових 3 урахуванням активності кандидатів, дослідницької позиції, об'єктивації поведінки та партнерського спілкування.

Ефективність проведеного тренінгу перевірено за допомогою критерію $\mathrm{W}-У$ Улкоксона, для чого виконано порівняльний аналіз результатів опитування експериментальної групи до й після тренінгу, який засвідчив статистично значущі відмінності за всіма показниками. Отже, тренінг дав змогу призовникам експериментальної групи підвищити рівень готовності до служби в Збройних силах України.

Військова діяльність як складник військової служби спрямований у мирні часи на підтримання бойової готовності збройних сил для забезпечення життєво важливих інтересів країни, під час війни - на знищення ворога. Навчально-бойова діяльність готує військовослужбовців до можливих бойових дій, відбуваючись безпосередньо у військових частинах, навчальних військових підрозділах Збройних Сил України; бойова - проходить в умовах військової сутички. У реальних бойових умовах воїни ризикують життям, бойові дії потребують високого напруження всіх фізичних і духовних сил.

Військова служба зумовлена значними фізичним та психологічним навантаженнями, які супроводжують весь термін строкової військової служби, тому вимагає відповідної готовності призовника до проходження служби для уникнення проблем дезадаптації під час екстремальних ситуацій. Готовність до служби в армії полягає в здатності успішного виконання вимог військової діяльності на початковому етапі, адже високий рівень готовності скорочує адаптаційний період, даючи змогу зосередити зусилля на вдосконаленні необхідних для служби навичок і вмінь.

За результатами констатувального експерименту встановлено, що більшість призовників мають достатній для служби в армії рівень нервово-психічної стійкості й поведінкової регуляції, стійкий рівень працездатності у звичних умовах життєдіяльності. Проте в частини 
кандидатів на військову службу спостерігається нестабільний рівень працездатності в екстремальних умовах діяльності, ускладнена адаптація до нових умов життєдіяльності. Рівень морально-етичної нормативності призовників достатній. Вони загалом зорієнтовані на дотримання загальноприйнятих і соціально схвалених норм поведінки, корпоративних вимог; у повсякденній життєдіяльності групові інтереси, як правило, переважають над особистісними; проте наявні кандидати з низьким рівнем, що зумовлено низьким рівнем соціалізації, недотриманням загальноприйнятих норм поведінки. Більшість юнаків мають достатній і високий рівні стійкості, що відповідає вимогам до військовослужбовців в умовах бойової діяльності, проте кожний шостий призовник показує мінімальну відповідність указаним вище вимогам.

Результативність проведеного тренінгу засвідчила статистично значущі відмінності за всіма показниками: рівнями стійкості до бойового стресу, військово-професійної спрямованості, нервовопсихологічної стійкості, емоційної стійкості. Отже, тренінг дав змогу призовникам експериментальної групи підвищити рівень готовності до служби в Збройних Силах України.

\section{АНОТАЦІЯ}

У статті визначено важливість психологічної готовності кандидатів до служби в Збройних Силах України. Подано психодіагностичний інструментарій формування компонентів психологічної готовності до служби. Виокремлено проблематику терміна «психологічна готовність», який розглядається в різних аспектах психологічної готовності, використання яких у різних авторів не збігається. Зазначено теоретичні основи готовності до професійної діяльності, а також установлено, що діяльність військовослужбовців за бойових обставин характеризується впливом на психіку різних стрес-факторів. 3'ясовано, що військова діяльність як складник військової служби спрямована в мирні часи на підтримання бойової готовності збройних сил для забезпечення життєво важливих інтересів країн, під час війни - на знищення ворога.

Зазначено й узагальнено результати теоретичного дослідження, яке уможливило виділення трьох основних компонентів психологічної готовності призовників до військової служби. 3'ясовано, що головними структурними елементами психологічної готовності військовослужбовців вважається мотиваційний, пізнавальний, емоційний i вольовий компоненти. Проведено емпіричне дослідження особливостей психологічної готовності до військової служби в Збройних силах України. За результатами констатувального експерименту встановлено, що 
більшість призовників мають достатній для служби в армії рівень нервовопсихічної стійкості й поведінкової регуляції, стійкий рівень працездатності у звичних умовах життєдіяльності. 3'ясовано, що найбільш ефективною допомогою вважається групова форма роботи, а саме метод соціальнопсихологічного тренінгу, який застосовують у системі підготовки спеціалістів різного профілю. Результативність проведеного тренінгу засвідчила статистично значущі відмінності за всіма показниками: рівнями стійкості до бойового стресу, військово-професійної спрямованості, нервово-психологічної стійкості, емоційної стійкості.

\section{ЛІТЕРАТУРА}

1. Авдеев В.В. Психотехнология решения проблемных ситуаций. Москва : Феникс, 1992. 128 с.

2. Голованов Ю.Н. Оценка и формирование психологической готовности сотрудников специальных подразделений МВД России к деятельности в экстремальных ситуациях : дисс. ... канд. психол. наук : 19.00.06. Санкт-Петербург, 2001.167 с.

3. Дружинин В.Н. Психология общих способностей. СанктПетербург : Питер, 2002. 368 с.

4. Дубовицкая Т.Д. К проблеме диагностики учебной мотивации. Вопросы психологии. 2006. № 1. С. 73-78.

5. Дунин Г.С. Психологическая готовность сотрудников МВД России к деятельности в чрезвычайных ситуациях. Вестник Московского университета МВД России. Москва, 2006. № 1. C. $133-136$.

6. Дьяченко М.И. Психологические проблемы готовности к деятельности. Минск : БГУ, 1976. 176 с.

7. Евсюкова Н.И. Психолого-педагогические условия формирования готовности юношей допризывного возраста к службе в вооруженных силах : монография. Владимир : ВГГУ, 2009. 192 с.

8. Кабаченко Т.С. Методы психологического воздействия: учебное пособие. Москва : Пед. о-во России, 2000. 530 с.

9. Кокун О.M. Діагностування психологічної готовності військовослужбовців військової служби за контрактом до діяльності у складі миротворчих підрозділів : методичний посібник. Київ : НДЦ ГП 3СУ, 2011. $153 \mathrm{c}$.

10. Колесніченко О.С. Психологічна готовність працівників МНС України до професійної діяльності в екстремальних умовах : автореф. дисс. ... канд. психол. наук : 19.00.09. Харків, 2011. 23 с.

11. Кондрашова Л.В. Моральна психологічна готовність студента до вчительської діяльності. Київ : Вища школа, 1987. С. 40. 
12. Конопкин О.А. Психологические механизмы регуляции деятельности. Москва : Наука, 1980. 320 с.

13. Левитов Н.Д. О психических состояниях человека. Москва : Просвещение, 1964. 344 с.

14. Максименко С.Д., Носенко Е.Л. Експериментальна психологія : підручник. Київ : Центр учбової літератури, 2008. 360 с.

15. Матохнюк Л.О. Формування психологічної готовності майбутніх інженерів-прикордонників до професійної діяльності : дис. ... канд. псих. наук : 19.00.07. Хмельницький, 2006. 219 с.

16. Моргун В.Ф. Емоційний інтелект у багатовимірній структурі особистості. Постметодика. Полтава, 2010. № 6. С. 2-14.

17. Окуленко I.M. Психологічна готовність льотного складу до діяльності в умовах тривалих перерв між польотами : дис. ... канд. психол. наук : 19.00.09.Хмельницький, 2007. 304 с.

18. Пономаренко В.А. Социально-психологическое содержание боевого стресса. Психологический журнал. 2004. Т. 25. № 3. С. 98-102.

19. Пуни А.Ц. Некоторые психологические вопросы готовности к соревнованиям в спорте. Москва : Физкультура и спорт, 1973. С. 5.

20. Равикович С.И. Развитие психологической готовности старших подростков к производительному труду : автореф. дисс. ... канд. психол. наук : 19.00.07 «Педагогическая психология». Москва, 1986. 14 с.

21. Семиченко В.А. Психология деятельности. Киев : Издатель Эшке А.Н., 2002. 248 с.

22. Сиротин О.А. Психолого-педагогические основы индивидуализации спортивной подготовки дзюдоистов : монография. Челябинск, 1996. 315 с.

23. Собчик Л.Н. Стандартизированный многофакторный метод исследования личности СМИЛ (ММРІ). Санкт-Петербург : Речь, 2000. $219 \mathrm{c.}$

24. Томчук M.I. Психологія готовності учнів до служби у Збройних силах України. Вінниця : Нова Книга, 1993. 166 с.

25. Узнадзе Д.Н. Психологические исследования. Москва : Наука, 1966. $233 \mathrm{c}$.

26. Шандрук С.К. Специфіка підготовки практичних психологів до професійної діяльності: проблеми підготовки і підвищення кваліфікації практичних психологів у вищих навчальних закладах. Київ : НікаЦентр, 2002. С. 32-34.

27. Ягупов В.В. Військова психологія: підручник для студ. ВНЗ. Київ : Тандем, 2004. 376 с.

28. Maddi S.R. The personality construct of hardiness, III: Relationships with repression, innovativeness, authoritarianism, and performance. Journal 
of Personality. 2006. Vol. 74. P. 575-598. DOI: 10.1111/j.14676494.2006.00385.x.

29. Orr S.P., Pitman R.K., Lasko N.B., Herz L.R. Psychophysiologic assessmen of post-traumatic stress disorder imagery in World War II and Korean combat veterans. 1993. V. 102. P. 152. DOI: 10.1037/0021-843X. 102. 1. 152.

\section{Information about the authors:} Harkusha I. V.,

$\mathrm{PhD}$ in Social Communications, Associate Professor, Associate Professor of Pedagogy and Psychology Department

Alfred Nobel University 18, Naberezhna Sicheslavska St., Dnipro, Ukraine, 49000

Kaiko V. I., Candidate of Psychology, Associate Professor, Associate Professor at the Department of Criminalistics, Forensic Medicine and Psychiatry Dniprovsky State University of Internal Affairs 26, Gagarin Avenue, Dnipro, Ukraine, 49005 